
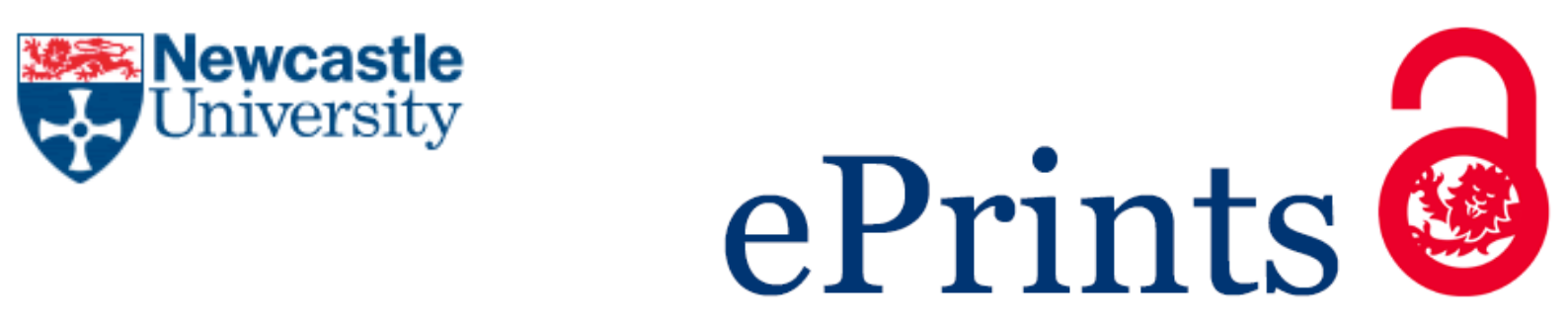

Whittle A, Mueller F, Mangan A. Storytelling and 'character': Victims, villains and heroes in a case of technological change. Organization 2009, 16(3), 425442.

\title{
Copyright:
}

This is the authors' accepted manuscript of an article published in its final form by Sage, 2009

DOI link to article:

http://dx.doi.org/10.1177/1350508409102305

Date deposited:

$11 / 05 / 2015$

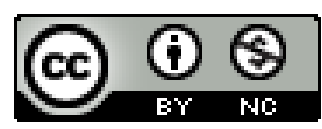

This work is licensed under a Creative Commons Attribution-NonCommercial 3.0 Unported License 
This is the author(s) personal version of the manuscript, as accepted after the review process but prior to final layout and copyediting by the publisher. The final version is published as:

Whittle, A., Mueller, F. \& Mangan, A. (2009) 'Storytelling and 'Character': Victims, villains and heroes in a case of technological change. Organization 16(3): 425-442.

Readers are kindly asked to use the official publication in references.

\section{Storytelling and 'Character': Victims, villains and heroes in a case of technological change}

In this paper we examine the role of stories in the temporal development of images of the self at work. Drawing on an in-depth case study of technological change in a UK public-private partnership, we highlight the role of stories in the construction, maintenance and defence of actors' moral status and organizational reputation. The analysis focuses on the development of one 'character' as he shifted from the role of innocent victim to implied villain to heroic survivor within the stories constructed during routine work conversations. We argue that stories are intimately linked to the forms of 'moral accounting' that serve to deal with the challenges to 'face' and social positioning

that accompany 'failed' organizational change. Stories, we suggest, are likely to be invoked when an interactional encounter threatens the participants' sense of social worth. Stories in which we present ourselves in a positive light - for instance as virtuous, honourable, courageous, caring, committed, competent - comprise a key component of face-saving strategies designed to maintain our social positioning: processes that are often intensified during periods of organizational change. 


\section{Storytelling and 'Character': Victims, villains and heroes in a case of technological change}

\section{Introduction}

In this paper we draw on data from a qualitative study of a UK public-private partnership to examine the stories people tell about themselves and their work during times of organizational change. Our study examines the moral stories that are told during contested situations - the sort of everyday 'social dramas' (Turner, 1982), more or less plausible accounts (Scott \& Lyman, 1968), that accompany periods of organizational change. Our central argument is that story fragments need to be studied as part of everyday workplace conversations that accompany the negotiation of workplace problems and contribute to the temporal development of protagonists' 'character'. Story-lines can be crafted around plots such as 'hard times' or 'hero triumphing over the odds' (Harre, 1979/93: 162). Our approach is predicated on the notion that not only are stories "precarious artefacts” (Gabriel, 2000: 3), but they can exist in fragmented and distributed form. In contrast to others, we argue that this precariousness means that a story does not have to comprise an integral, complete and linear narrative.

In this paper we seek to theorise those stories created during the mundane and routine acts of moral accounting for ourselves and our actions at work. An example could be the apparently 'trivial' act of accounting for why a colleague was not told they had left the headlights on their car switched on (Gabriel, 2000: 40-41). By moral accounting we mean situations that involve the social position of the self, including issues of rights, duties, obligations, responsibility and potential blame (van Langenhove \& Harre 1999: 23). Indeed, according to Goffman (1959a: 23), “As performers we are merchants of morality". The distinctive contribution of this paper lies in our analysis of how consecutive acts of moral accounting contribute to 'character development' (Bruner, 1986: 20-21). The key question for this paper is thus: how do the stories that people tell during periods of organizational change relate to the development of the characters involved? 


\section{On Stories and Storytellers}

What is a story and why is it important? According to the literature, stories are important because they comprise a primary medium through which members make sense of, account for, enact and affect the organizations they work for. However, disagreement exists around the question of what actually constitutes a story. According to Gabriel (2004a, 2004b: 63), much is lost by claiming that all instances of talk and text in and of organizations can be understood as stories - this, he suggests, "inevitably assist[s] in making storytelling ... moribund” (Gabriel, 2000: 29). For Gabriel, stories are specific types of discourse that draw on particular poetic and literary genres, follow certain theatrical styles and are often delivered with entertainment and spectacle in mind (Gabriel, 2000: 9-10). Others advance a broader and more inclusive definition of a story by emphasising the importance of having events and characters arranged in a meaningful way into a more or less well-defined and coherent plot (eg. Czarniawska, 1999), as part of the never-ending construction of meaning in organizations (Czarniawska, 1997: 28; 1999: 22).

In this paper we follow this latter, broader definition by viewing stories as instances of talk or sequences of interaction that attempt (with varying degrees of success) to place a particular order, emphasis and meaning upon events and actors (including the storytellers themselves). Stories, we suggest, are not reserved exclusively for the polished and rehearsed monologues produced by senior executives, for example in speeches, memos and newsletters, which are designed to inspire the workforce. Nor are they always a coherent sequence that is (re)told with the purpose to entertain in mind. We follow the turn towards so-called 'small stories' in narrative research described by Georgakopoulou (2006) by paying attention to the stories created in the informal, un-rehearsed and sometimes messy conversations that take place in everyday work settings. Rather than always comprising an uninterrupted sequence of sentences (the typical narrated story), we agree with Boje (1991), Brown \& Humphreys (2003: 128) and Brown, Humphreys \& Gurney (2005: 323) that stories can also be constructed piece-meal through fragments spread throughout conversations. Often, "stories are brief and fragmented across extended and interrupted discourse ...” (Boje, 1991: 109).

Literature on organizational storytelling has made much progress on advancing our understanding of what types of stories are told in and about organizations - such as the tragedy, romance, comedy or satire (Skoldberg, 2002), and how these stories 
are crafted - such as through processes of focusing on (or filtering out) certain events and characters, such as heroes, villains, fools and magic wands (Gabriel, 2000: Ch.7). Much less attention, however, has been directed towards understanding why stories are crafted and what stories do for the social positioning of those who tell them - the main focus of our paper. Our aim is to highlight the value of a story-telling perspective for understanding the central element of organizations, that is, work itself. Surgeons, for instance, can make sense of their experiences with patients in terms of different plots, such as the atrocity, the cliff-hanger, the mystery and so on (Atkinson, 1995: 4). Thus, work must be understood not only as something that people 'do' but also implicated in who people 'are': “it is through storytelling that people's lives are experienced and made meaningful, and their identities constructed” (Stockoe \& Edwards, 2006: 56; also van Langenhove \& Harre, 1999: 16). For example, in an indepth study of middle managers' storytelling, Sims (2003) uncovered the vulnerability and anxiety felt by managers as their stories were "contested, denied or simply ignored by others” (p. 1196).

While many authors have sought to show how identities are implicated in the construction of organizational stories (eg. Czarniawska, 1997: Ch 7; Czarniawska, 1998: 41; Gabriel, 2004a: 3), existing research has tended to analyse stories on their own terms and pay less attention to how they are situated in and implicated in members’ everyday working lives. For example, Gabriel (2000: 154-163) analyses stories about computers, IT experts and 'cock-ups'. But in his case, like others, analysis has tended to focus on the plot, genre, metaphor or style of stories about periods of organizational change told to a researcher during an interview or field visit. Less attention has been paid to what happens to these stories and their narrators outside of these interview contexts. Are stories told to researchers reproduced at other times and in other work contexts? If so, what happens when these stories are reproduced? Are stories always accepted and believed? Or can they be disputed and challenged? If so, what are the consequences for those involved? The focus of this paper is thus on what story-telling and moral accounting achieves in the practical contexts of work.

As Hales (2002: 63) argues, “managers are not merely entangled within webs of morally neutral information but are also compelled to try to spin that information in particular ways in order to accrue praise and avoid blame”. Allocating blame, or offering an excuse, only makes sense within a moral order, i.e. where the people 
involved attempt to construct a particular moral position (van Langenhove \& Harre, 1999: 26). Story-telling can be used to position oneself in a positive light and avoid damage to one's social status, for instance by presenting oneself as decent, honest or honourable. Indeed, "offering an excuse by way of explanation is not just a way of resisting an accusation of guilt, but is also an act of self-positioning” (van Langenhove \& Harre, 1999: 26). In fact, according to Harre (1979/93: 162), the presentation of an acceptable person, appropriate to the scene and the part in the action comprises a major human preoccupation. We suggest therefore that stories and story-telling can be linked to the Bruner's notion of 'character' (Bruner, 1986: 20-21, 37-39): there is plight, which can include being subjected to guile, deceit and misunderstanding. There are characters who overcome their plight, including an uneven distribution of consciousness in this process.

While Boje (1991) correctly identifies the fragmented and distributed nature of organizational storytelling, his focus on incremental refinement suggests a somewhat unitary view of organizational life. Boje recognizes that "alternative stories with alternative motives and implications" can be told, but he focuses on how actors work collaboratively to refine the stories told by others. Instead, we focus on what happens when stories come into conflict with each other. This is particularly important in studies of organizational change, when the meanings, identities and practices that accompany the change are under negotiation (Beech, 2000). As Boje, Oswick and Ford (2004: 572) point out, "there is always more than one possible reading of any organizational event or situation” (Boje, Oswick and Ford, 2004: 572), leading to conflicting stories about organizational change.

Brown and Humphreys (2003) study of an organizational merger found that distinct and competing narratives were constructed amongst different organizational groups. Senior managers, for example, told a story of competent leaders securing the future of the company, whilst staff portrayed themselves as victims of incompetent managers and ineffective strategies. We extend this work in two respects: first, by examining what happens when competing stories such as these are negotiated in realtime interaction; second, by examining how these interactions link to the moral characters of those involved. Our aim here is thus to explore the role of story-telling in the ongoing process of moral accounting and the development of character(s) over time. 


\section{Methodology}

Research Site The research was conducted in a UK public-private partnership called Back2Work (all names are pseudonyms). Back2Work delivers employment services to jobseekers in areas of high unemployment contracted from the UK Department for Work and Pensions (DWP).

\section{Data Collection}

Fieldwork observation was particularly important to this study because of the methodological limitations of relying solely on interviews. When analysing interview data, it is difficult to be certain of the extent to which the stories told during interviews are prevalent at other times and hence whether they have a wider significance in the organization under study. Furthermore, while stories told during interviews are rarely contested by the interviewer, this may not be representative of the sort of plurality, heterogeneity and contestation that is routinely present in organizations (Humphreys and Brown, 2002). For instance, in the formal interview discussed below (see Story-Line 1), the researchers in this study politely remained silent, nodded and smiled to reassure and encourage the two interviewees, Guy and Desmond, as they constructed their story. Our questions and comments were usually for purposes of clarification and elaboration. Indeed, we deliberately used this sort of confirmation and reassurance to encourage interviewees to feel relaxed and 'open up'. However, the corroboration we offered during the interview was certainly not representative of the contestation and negotiation we observed during the rest of the fieldwork visit, detailed in Story-Lines 2 and 3 below. In other words, the storytelling that occurs during research interviews may not be representative of the storytelling that occurs in other naturally-occurring work conversations. The "in situ and in vivo" (Zilber 2007, p. 1051; Boje, 1991: 109) fieldwork observation was therefore central to our methodology because it enabled us to investigate storytelling in practice - the focus of this paper.

We adopted 'methodological flexibility' (Amit 2000) which enabled us to collect data that was not planned in advance as part of the formal 'research design'. 
One good example was when we took up the impromptu offer of 'sitting in' on the trouble-shooting meeting - detailed in Story-Line 3 below. Such flexibility enabled us to observe first-hand the re-negotiation of the story we were originally told during the formal research interview (see Story-Line 1).

\section{Data Analysis}

In this paper we focus on a single fieldwork visit rather than attempting to represent the plethora of stories we gathered during the five-month fieldwork period. The latter approach would undoubtedly enable us to offer a greater breath of stories, but crucially would not be able to offer the depth of analysis needed to show the development of stories in situ, as Boje (1991) suggests. Focusing on a single interactional event is standard procedure in many disciplines, such as linguistics and conversational analysis, but is also crucial for studying storytelling, according to Antaki and Horowitz (2000: 157), as it enables us to track "the development of a piece of social action as it accumulates over the length of an episode; that is especially apt in the case of a storytelling, which can build over many turns".

As Alvesson and Kärreman (2007) highlight, data is constructed through dialogue with the "paradigmatic, political, theoretical, methodological, and social predispositions” of the researcher (p. 1270). There were many stories that we chose not to include in this paper - our decision to select these three data extracts and to transcribe them in this way therefore reflects our theoretical presuppositions. For example, our decision to treat the informal conversation in the staff kitchen in Extract 2 as 'data', as opposed to a trivial side-issue from the 'real' business of the research interview, reflects our interest in what happens when stories are re-cast by others.

\section{Storytelling and 'Character': The Case of Back2Work}

As part of the study, the researchers visited an office in South Wales that had recently implemented Quality Framework (QF), a new information system. We were hosted for the day by 'Guy', an apparently self-appointed office 'IT guru' who had been active in 'troubleshooting' the change process during the implementation period. In this paper we analyse three separate extracts from the data collected during the fieldwork visit that construct three different 'story-lines' about the change process (van Langenhove \& Harre, 1999: 18-19). 


\section{(A) Story-Line 1: A tale of 'innocent victims' and 'brave heroes'}

When we arrived at the South Wales office we were ushered into the staff kitchen by Guy, who apologised for not having a more suitable venue for conducting the interview - the office was often very crowded, he explained. After meeting Desmond, one of the IT trainers involved in the Quality Framework (QF) project, and introducing ourselves and the background to our study, we turned on the tape-recorder and began the formal interview by asking Guy and Desmond about their experience of the roll-out of the QF system.

Desmond: $\quad$ The feedback from [the user testing] was 'great, it's just what we need as a business'. Am, however, we have got teething problems, haven't we, Guy?

Guy: $\quad$ Yeah. (Chuckles).

Desmond: $\quad$ Am, some of it is to do with you know, people. People issues and you know, they haven't listened at training and doing things not quite right. But other things, there is slight bugs in the system, yeah?

Guy: $\quad$ Slight?

Researcher 1: $\quad$ Slight ...

Desmond: Yeah, well. (Guy giggles in background) You [looking at Guy] probably know more about it actually because I’ve been away.

Guy: The trouble we've got now is ... we're having paperwork in, nowhere to put it on the [IT] system. Because the process wasn't quite right we had to file it and so, yeah, it's a bit of a mess. So it's going to take months to recover from this.

Researcher 1: $\quad$ So that happened because the system went live?

Guy: $\quad$ And wasn’t right (raps fingers on table). It wasn’t correct.

Desmond: It wasn’t perfect.

Researcher 1: $\quad$ So is that an actual bug in the actual technology itself?

Guy: $\quad$ Ah, it might be the technology, for some of it, and also who checked the process hadn't checked it well enough. It hadn't been run alongside a live system.

Desmond: $\quad$ Yeah, it wasn’t piloted. 
Guy:

To test all of the possible variables which would happen. ... There's paperwork which goes to the Job Centre which the dates weren't quite right and there's bugs like that.

[discussion about possibility of shutting down new IT system and restarting when the 'bugs' are fixed, including implications for next quality audit]

Desmond: $\quad$... The company were too quick to try to push this in. ... But for me that's not the right - we shouldn't be doing things that way. It should have been run in parallel with something. One of, one zone should have been piloting this for, you know, a few weeks or months or ...

Guy: $\quad \quad \ldots \ldots$ the quality isn't there now, is it? And there's a bonus, for each time we get the quality right.

In this research interview, Guy and Desmond jointly constructed a story about the 'failures' of the change process that frames the events and characters involved in a particular way. Following Gabriel (2000: 36-39), who discusses eight types of attributions, we can see how certain motives and responsibilities are enacted. For example, the interviewees present themselves as committed employees who care about the business ("it's just what we need as a business", "there's a bonus, for each time we get the quality right”) and who should be credited with identifying the problem ("It hadn’t been run alongside a live system”) and trying to find a solution (“It should have been run in parallel with something”). Following Gabriel's (2000: 36-39) typology, the story invokes certain causal connections - for instance, the IT system and the implementation process is identified as the cause of the 'problem' ("there is slight bugs in the system”, “it wasn’t piloted”). Certain emotions are also suggested when the interviewees describe the frustration of dealing with a (purportedly) poorly developed and tested system (rapping of fingers on table, "It's going to take months to recover from this.”). There is also story glossing going on with the aim that the "referent experience becomes sensible in new ways after having been glossed” (Boje (1991: 117): Desmond retells a fragment as 'slight bugs in the systems', Guy tells it as 'the process wasn't quite right'.

In Story-Line 1, the technology is portrayed as 'faulty' and 'disloyal' because of a) 'bugs' arising from being hard-coded from incorrect mapping of the work process (“Because the process wasn’t quite right”), b) inadequate testing (“To test all 
of the possible variables.”), c) a 'rushed' implementation ("The company were too quick to try to push this in.”) and d) not being piloted alongside the pre-existing manual system (“It hadn’t been run alongside a live system”, “It wasn’t piloted”). The interviewees, on the other hand, portray themselves as 'loyal' and 'competent' employees because of a) their knowledge of the 'correct' process of paperwork flow ("we're having paperwork in, nowhere to put it on the [IT] system"), b) their commitment to the best interests of the organization, namely by passing the audit process and securing the associated benefits (“...the quality isn’t there now, is it? And there's a bonus, for each time we get the quality right”). Guy in particular seems to take personal responsibility for ensuring 'bugs' in the new system were diagnosed and repaired so that the South Wales office, and the company as a whole, did not suffer financially. He also seemed irritated and almost distressed (evidenced from his nervous laughter and drumming of fingers on the table) about the problems they were currently facing. In short, both interviewees seemed keen to point out that the problems they were facing were due to the design of the system as opposed to errors on the part of South Wales staff, casting themselves as either innocent victims of a technological disaster, or - following the plot of David and Goliath - the gallant heroes fighting against the mighty 'Goliath' of the faulty IT system, in service of the noble and worthy cause of "the business".

\section{(B) Story-Line 2: An alternative moral story}

Towards the end of the research interview, the conversation was suddenly interrupted as two senior managers, Bob and Jonathan, came into the kitchen to make a cup of coffee. Bob immediately recognised one of the researchers from a Quality Framework training event the previous week. Bob was the business sponsor of the change project and was instrumental in generating the idea for the new system and leading the change process. Jonathan introduced himself as one of the regional managers responsible for the South Wales office. After some initial social chit-chat with the researchers, Bob started chatting with Guy about their plans for a 'troubleshooting' meeting about Quality Framework later that day. As they waited for the kettle to boil, the tape-recorder was still rolling - capturing their informal conversation about the change project. 
Bob: $\quad$ Are we going to spend a couple of hours on that later, aren't we?

Guy: $\quad$ Yeah, you've seen the email?

Bob: $\quad$ I have, but I will say - and in openness as well - I think we're the only ones having any problem by and large. I don't mean in terms of some of the dates -

Guy: $\quad$ - yeah -

Bob: $\quad$ - but in terms of attitude and what have you ${ }^{1}$, which $\mathrm{I}-$ so we need to look at that.

Guy: $\quad$ Yeah.

Bob: $\quad$ (Raises voice) It's going to work because it's something that I've asked for, something that I've backed and it's going to work. So I'm not saying that for yourselves here [nodding at researchers]... but from our point of view I want it to deliver what it's intended to do. ...

Guy: $\quad$ Bob, Birmingham’s had the same problems.

Bob: $\quad$ They went live Monday.

Guy: $\quad$ Yeah and pulled the plug. ...

Bob: $\quad$ But I'm not going to draw any conclusions. ... It's going to work.

[Partly inaudible: Bob mentions something about the 'kickback' (resistance) being something to do with 'human nature'].

Bob: $\quad$ That's all I'd ask you to be, is not to be frustrated.

Guy: $\quad$ We are [frustrated].

Bob: Let's work with it. Let's find out what the issues are. Let's bring about the solutions. Yeah?

Guy: $\quad$ But I did shout [complain] a bit last week, when all this was going on because nobody was listening. ...

Bob: $\quad$ But who did you speak to?

Guy: $\quad$ Everybody!

Bob: Who's everybody?

Guy: $\quad$ (laughs) Well - [the IT helpdesk] first of all.

Jonathan: (Interrupting) I think you're being on top of Guy ${ }^{2}$ there. I think he had difficulty in actually getting anybody to listen to him, you know?

\footnotetext{
1 'What have you' is a colloquial expression usually meaning 'etc' or 'likewise'

${ }^{2}$ The phrase 'on top of' is related to the phrase 'on their back', meaning to bother or criticise someone.
} 
What is interesting about this conversation is the way in which Bob attempts to contest the story told by Guy and Desmond in the interview just moments before. A new set of causal connections (Gabriel, 2004a) and vocabulary of motives (Mills, 1940) is introduced which casts Guy and his colleagues in the South Wales office as the 'real' cause of the problems they have been experiencing, not the bugs in the new system - directly contradicting Story-Line 1 above. Bob does this by implying that other offices have not experienced the same problems ("I think we're the only ones having any problem by and large”). While he is careful to avoid a direct accusation of blame on the part of the two interviewees by keeping his talk at a general level ("in terms of attitude and what have you”), he nevertheless contradicts the story told by Guy and Desmond in the interview a few minutes before. He questions the motives of others by implying a resistant "attitude" in order to "protect the storyteller's own version of events” (Antaki \& Horowitz, 2000: 158). Bob’s alternative story-line suggests there are no major problems with the technology, but problems with staff attitude instead.

It is noteworthy that Guy spends considerable time and effort trying to 'butt' back into the conversation to emphasise that there is indeed a problem and it lies with the IT system (as per Story-Line 1 above), not his (or anyone else's) 'attitude' or competence. Guy refutes Bob's suggestion that their office is the 'problem' by highlighting the similar problems faced in another office ("Bob, Birmingham's had the same problems”). Guy also tried to highlight the efforts he had made to 'flag up' and try to resolve the problems ("I did shout a bit last week, when all this was going on because nobody was listening”). This can be read as an attempt to establish for himself a different (more favourable and honourable) 'vocabulary of motives' (Mills, 1940), one which portrays himself as acting from a genuine and committed concern for the business (not a resistant employee with a bad attitude). Guy displays the temper that is one of the "regular features of computer stories" (Gabriel, 2000: 162) ("I did shout a bit”), as are "disparaging” (Gabriel, 2000: 166-7) views of the IT department (“nobody was listening”). Jonathan corroborates Guy’s storyline here by leaping to his defence and verifying his definition of the situation ("he had difficulty in actually getting anybody to listen to him”).

By refusing to corroborate Guy's story ("I'm not going to draw any conclusions") and refusing to accept that the IT system is the villain ("it's going to 
work"), Bob re-casts the technology as a 'correct' and 'working' artefact - in contrast with the 'evil-villain' machine portrayed by Guy earlier. He questions the validity of Guy's account by arguing that other offices have not experienced any of the 'faults' identified by Guy. Instead, the villain of Bob’s story is now the local staff (and their 'attitude’, 'kickback' and 'human nature’). In spite of Jonathan’s attempt to support Guy's story and defend his reputation as competent, genuinely concerned and committed ("I think you're being on top of Guy there”), Guy is clearly unsuccessful in reproducing the story he told the researchers (and which we accepted) to his boss.

Why, then, did this clash of competing stories occur? It is important to reflect upon underlying power inequalities, including that Bob was the original sponsor behind the project and thus had considerable identity-investment and careerinvestment in making sure the project succeeded. As the senior 'sponsor' of the project, Bob could be said to have a vested interest in defending the 'fidelity' of the technology. As he himself puts it, the new IT system is "something I've backed and it's going to work”. Having invested his reputation and career in the project, Bob implies his position of power and he seeks to create a moral order in which the staff rather than the technology are blamed for any problems. The fate of the new IT system was therefore intimately linked to Bob’s own character, power and reputation in the organization. Not all stories are equal, therefore, and hierarchical power relations are at play here, particularly given that Bob is Guy's boss.

Viewing the change project as part of Bob's character also helps us to understand how Bob deals with his own stake or interest in the situation in his version of the story. Stake must be carefully handled in interaction because of the potential that "anything that a person (or group) says or does may be discounted as a product of stake or interest” (Potter, 1996: 110). By using a form of stake confession, Bob appears to take personal responsibility for the change process by acknowledging that any problems that arise are his concern ("It's going to work because it's something that I've asked for, something that I've backed and it's going to work"). Bob also attempts to bracket off the grievances of the audience by portraying them as both unusual and local ("I think we're the only ones having any problem by and large”), hence defending both the technology and the change project itself - not a surprising move given that he was instrumental in designing both. 
Guy, in contrast, attempts to make the situation appear routine - a case of 'routinisation' (Bourdieu, 1992: 109) - and externalise responsibility for the situation by employing 'neutralisation' (Bourdieu, 1992: 109) when he states: “Birmingham’s had the same problems ... and pulled the plug”. This plot-line makes Guy appear as the innocent victim of the universal problems brought about by the 'faulty' machine. In Gabriel's (2000: 154) collection of computer stories, computers can feature as villains, scapegoats or heroes. In this informal conversation in the staff kitchen the narrators weave together an evolving story-line where Guy (and his colleagues) emerge as the (implied) "villain(s) of the piece” (Gabriel, 2000: 160). In contrast to the social positioning and moral accounting performed in the research interview just minutes earlier (see Story-Line 1 above), Guy finds his moral standing and organizational reputation in question - he is left looking like a less-than-competent employee that was determined to find faults in the new IT system which perhaps did not exist. Guy's social positioning was thus more ambiguous and contested in his everyday workplace conversations than the formal interview suggested. In short, what appears to be happening is a battle between two versions of the same story motivated by two different projects of social positioning and moral accounting. This battle continued in the 'troubleshooting' meeting later that same day.

\section{(C) Story-Line 3: 'Heroic Survivor'}

Later on that afternoon, Guy and Bob met up for an informal 'troubleshooting' meeting to look into the issues surrounding the new Quality Framework system. Guy sat with Bob at a PC and logged into the system to show him where the 'problems' lay - according to his story, at least. The two researchers also sat around the computer screen to observe and take written notes. The following extract is taken from the fieldnotes written during the meeting (verbatim quotes) and after the event (our narrative).

Guy seemed to be trying to convince Bob that the problems Wales had experienced with QF were due to the technology not reflecting the actual work process, not their attitude/competence/lack of ownership (as Bob suggested in the kitchen earlier).

Guy: So it's not us, is it. It's process. 
Bob: I will support you on that one because it affects overstayers ${ }^{3}$. I'll speak to Betty [from IT].

[Turns to speak to researchers]

Overstayers are a material breach of contract, they can take your contract away for things like that. In real business terms that's $£ 47$ million. .... I’ll raise these at the IT strategy meeting.

Guy: So it is process.

Bob: It's not, not just, it's about expectations. We had a good system before, others might not have had that, so they think it's an improvement.

Guy: But they'll have the same issues.

Bob: They might, but they might not notice them yet. .... These are just simple technical issues of the programming.

Guy points out that it takes about 10 seconds for the 'outstanding' page to load. Guy said something like 'see, Bob' (as if to delight in actually demonstrating the problems with the artefact) and that this adds up to a lot of wasted time for the quality team because they have to go into each individual record to see what's outstanding. Bob conceded that 'There is a speed issue there'. ... Guy defended himself by saying 'I did play hell ${ }^{4}$ last week' and said that they'll just have to be aware that for the next couple of audits they'll have to put in extra work.

Two competing definitions of the situation were forwarded during the conversation in the kitchen earlier that day (Story-Line 2). Guy had portrayed the recent IT implementation as a 'mess' because of 'bugs' in the system, which were still present in spite of his efforts to highlight and rectify them. Guy positioned himself as a morally upstanding employee who was aligned with corporate goals and dedicated to ensuring the success of the business. Bob, on the other hand, had challenged Guy's moral standing by laying blame with the bad 'attitude' of staff (including Guy), perhaps implying that Guy was more of a resistant/recalcitrant than a competent/committed employee. In these competing story-lines, we see the identities of the characters involved shift accordingly. Thus, as Davies and Harre (1999: 49) argue, rather than forming "a unified coherent whole”, our identity "shifts [as our] positions within varying storylines are taken up”.

\footnotetext{
${ }^{3}$ The company had a contractual requirement to get job seekers into work within a 13 week time span. Any jobseeker in the system longer than that is classed as an 'overstayer'.

${ }^{4}$ The term 'play hell' draws on the phrase 'giving them hell', meaning to complain or reprehend.
} 
This challenge to Guy's identity seemed to lead to intensive repair tactics and 'face' work during the troubleshooting meeting. By seeking to blame a faulty 'process', Guy invokes a new set of social and moral implications with regard to the responsibilities, expectations, rights and obligations of the different parties. In short, Guy seeks to externalise responsibility for the problems encountered by revealing the 'real' villain in the machine. Indeed, our field-notes remark on his apparent delight in demonstrating the 'problems' with the artefact. Guy attempted to shift 'blame' away from himself to the technology and regain thereby his status as a committed and competent employee, a 'hero' of the change process. Indeed, Bob now seemed to accept Guy's vocabulary of motives (i.e. my intentions are honourable and it is the technology that is to blame) by stating that he would 'support' Guy and raise the issue with other people ("I will support you on that one”). However, while Guy’s definition of the situation seems to be accepted and his positive sense of self (at least temporarily) restored, Bob also attempts to re-iterate and validate the alternative story he gave in the kitchen. He suggests that staff at the South Wales office may have 'resistant' attitudes because of their high expectations of the new system ("it's about expectations”) - because their office had a good record of quality in comparison to other offices ("We had a good system before").

In this meeting, Guy's identity is re-constructed as one of being 'resistant' to the change not because of a lack of identification with the goals of the change program (i.e. improved quality) but due to the strength of his identification. He emphasises a) the concern he has for quality (“they'll have the same issues”), b) the business impacts of the quality problems caused by the new system (e.g. 'this adds up to a lot of wasted time'), and c) his efforts to raise and resolve these issues ("I did play hell last week”). In short, Guy’s character progressed from 'innocent victim’ and 'brave hero' in the research interview, to 'implied villain' in the kitchen conversation to 'heroic survivor' in the trouble-shooting meeting. Yet Bob also succeeds in validating his original story-line and portraying the change he is responsible for as a valuable endeavour, in spite of "simple technical issues of the programming”, thus protecting his own character as a competent manager. To sum up, this re-negotiated storyline during the troubleshooting meeting enabled the two competing stories given earlier to be reconciled to ensure both parties are seen to bring valid interpretations of 
the causes of the problem and honourable intentions in portraying the situation that way - defending the character of both parties in the process.

\section{Summary, Analysis and Theoretical Implications}

In contrast to the approach typically adopted by U.S. scholars, where the emphasis is on stories glorifying or celebrating the prevailing corporate culture (Peters \& Waterman, 1982; Deal \& Kennedy, 1982), a more critical approach to stories and story-telling (e.g. Gabriel, 2000, 2004a, 2004b) has argued that "far from celebrating organizational achievements and successes, [stories] tend either to celebrate and laugh at the negative (cock-ups, failures, and reversals) or to bewail the tragic (traumata and injustices)” (Gabriel, 2000: 120). In this paper we have sought to examine empirically how the stories that accompany a technological 'cock-up' were negotiated. We found both comic and tragic elements, both celebration and bewailing. By presenting themselves as characters in a drama, the employees and manager in our study constructed competing storylines that attempted to defend and maintain their moral status and organizational reputation. We have argued that stories are intimately linked to the forms of 'moral accounting' that serve to deal with the challenges to social positioning (Harre \& van Langenhove, 1999: 8) that accompany 'failed' organizational change. Stories, we suggest, are likely to be invoked when an interactional encounter threatens the participants' sense of social worth. Stories in which we present ourselves in a positive light - for instance as virtuous, honorable, courageous, caring, committed, competent, and so on - comprise a key component of face-saving strategies designed to maintain our social position. In our study, managers and employees were engaged in some hard bargaining over who is to blame over a 'cock-up' and whose competence and commitment was in doubt. In fact, the competing stories differed over whether there was indeed a 'problem' in the first place.

Our approach departs from Gabriel (2000: 5), for whom stories are primarily defined in their desired effect, namely to entertain, and they need to be distinguished from "factual or descriptive accounts of events that aspire at objectivity rather than emotional effect”. For Gabriel, when narratives become claims or allegations, they are different from stories (Gabriel, 2004c: 72). For us, each speech act can have a number of desired or unintended effects, can attempt to portray different 'objective' pictures 
of events (e.g. whether there is a 'problem', what the 'problem' is, who is to blame etc) and can also be understood as stories with particular moral orders. This makes the boundary suggested by Gabriel's approach around what is (and is not) a story difficult to sustain. In our cases, stories were crafted in the form of a number of conversational fragments, but their purpose, in the first instance, was to identify why a change project was not working as planned. In addition to this instrumental intent, there were other desired performative effects: for example, one protagonist seemed to be keen to protect his workplace identity and be seen, by himself and others, as committed and competent. As Goffman (1971: 198) argues, the actor "constantly acts to provide information that he is of sound character and reasonable competency". Narrating a story is therefore about "making [] actions accountable from a particular (moral) perspective for particular situated purposes” (Bamberg, 2006: 144).

Our study has also highlighted the temporal evolution in social positioning and moral accounting. In our study, the story that was told during an interview was subsequently contested, re-told and re-negotiated several times during the same single working day. Thus, while individuals may prefer their moral version of events to dominate and their preferred identity to remain unchallenged, they may find they "struggle with the diversity of experience to produce a story of ourselves which is unitary and consistent” (Davies \& Harre, 1999: 49). The stories we tell about ourselves and our work, then, are always temporary and liable to challenge in spite of our best attempts to maintain a sense of coherence and continuity over time and between situations (Alvesson \& Willmott, 2002: 625).

Our distinctive contribution lies in utilizing Bruner's (1986) notion of character: we have shown not only the contestability of stories, and associated images of the self, but also the temporal development of such projections of the self - in our case from innocent victim and hero to (as re-cast by a senior manager) implied villain to (as later re-negotiated) heroic survivor. As such, we draw on and contribute to the socalled 'new' tradition in narrative research outlined by Georgakopoulou (2006) and Bamberg (2006) - by paying attention to not only the 'big stories' with a coherent progression of events and stable plot-lines characteristic of 'life histories' but also the short, fleeting and fragmented 'small stories' that are constructed in ordinary conversational contexts. We also highlight the value of viewing stories as discursive actions by examining what "people are doing when they tell stories" (Stokoe \& Edwards, 2006: 57). Stories, we suggest, can be used by social protagonists to 
develop their sense of moral standing, overcome the onslaughts on the self and, ideally, emerge victoriously (in our case as a heroic survivor), whose pride is still in tact. Thus, in conclusion, what gives our story-lines their unity, is ultimately the characters' development - "is the manner in which plight, characters, and consciousness interact to yield a structure that has a start, a development, and a 'sense of an ending'” (Bruner, 1986: 21).

\section{Acknowledgements}

The authors would like to thank the Economic and Social Research Council for supporting the research upon which this article is based (grant number RES-000-220914).

\section{References}

Antaki, C. and Horowitz, A. (2000) 'Using Identity Ascription to Disqualify a Rival Version of Events as "Interested"', Research on Language and Social Interaction 33(2): 155177.

Amit, V. (2000) 'Introduction: Constructing the Field', in V. Amit (ed) Constructing the Field: Ethnographic Fieldwork in the Contemporary World. pp. 1-18, London: Routledge.

Alvesson, M \& Kärreman, D. (2007) 'Constructing mystery: empirical matters in theory development’, Academy of Management Review 32: 1265-1281.

Alvesson, M. \& Willmott, H. (2002) 'Identity Regulation as Organizational Control: Producing the Appropriate Individual', Journal of Management Studies 39(5): 619-644.

Atkinson, P. (1995) Medical talk and Medical Work: The Liturgy of the Clinic. London: Sage.

Bamberg, M. (2006) 'Stories: Big or small: Why do we care?’, Narrative Inquiry 16(1): 139147.

Beech, N. (2000) 'Narrative Styles of Managers and Workers: A tale of star-crossed lovers', Journal of Applied Behavioural Science, 36(2): 210-228.

Bourdieu, P. (1992) Language and Symbolic Power. Cambridge: Polity Press.

Boje, D. M. (1991) 'The storytelling organization: A study of storytelling performance in an office supply firm’, Administrative Science Quarterly 36: 106-126.

Brown AD, Humphreys M. (2003) 'Epic and tragic tales: making sense of change'. Journal of Applied Behavioral Science 39(2): 121-144. 
Brown A.D., Humphreys, M. \& Gurney, P.M. (2005) 'Narrative, identity and change: a case study of Laskarina Holidays', Journal of Organizational Change Management 18(4): 312-326.

Bruner, J.S. (1986) Actual Minds Possible Worlds. Cambridge: Harvard University Press.

Czarniawska, B. (1999) Writing Management: Organization Theory as a Literary Genre: Oxford University Press.

Czarniawska, B. (1998) Narrative Approach to Organization Studies. London: SAGE.

Czarniawska, B. (1997) Narrating the Organization: Dramas of Institutional Identity. University of Chicago Press.

Davies, B. \& Harre, R. (1999) 'Positioning and Personhood', in R. Harre \& L. van Langenhove (eds.) Positioning Theory pp. 32-52, Oxford: Blackwell.

Deal, T.E. \& Kennedy, A.A. (1982) Corporate Cultures: The rites and rituals of organizational life. Reading: Addison-Wesley.

Gabriel, Y. (2000) Storytelling in Organizations: Facts, Fictions and Fantasies. Oxford: Oxford University Press

Gabriel, Y. (2004a) 'Introduction', in Y. Gabriel (ed.) Myths, Stories, and Organizations: Premodern Narratives for Our Times pp. 1-10, Oxford: Oxford University Press.

Gabriel, Y. (2004b) 'The Narrative Veil: Truth and Untruths in Storytelling', in Y. Gabriel (ed.) Myths, Stories, and Organizations: Premodern Narratives for Our Times pp. 1731, Oxford: Oxford University Press.

Gabriel, Y. (2004c) 'Narratives, Stories and Texts', in D. Grant, C. Hardy, C. Oswick \& L. Putnam (Eds) The Sage Handbook of Organizational Discourse pp. 61-78, London: Sage.

Georgakopoulou, A. (2006) 'Thinking big with small stories in narrative and identity analysis’, Narrative Inquiry 16(1): 122-130.

Goffman, E. (1959) The Presentation of Self in Everyday Life. Harmondsworth: Penguin 1990 Reprint.

Goffman, E. (1971) Relations in Public: Microstudies of the Public order. New York: Basic Books.

Hales, C. (2002) ' 'Bureaucracy-lite’ and Continuities in Managerial Work’, British Journal of Management 13(1): 51-66.

Harre, R. (1979/1993) Social Being. Oxford: Blackwell.

Humphreys M, \& Brown AD. (2002). 'Narrative of organizational identity and identification: a case study of hegemony and resistance', Organization Studies 23(3): 421-447.

Harre, R. \& van Langenhove, L. (1999) 'The Dynamics of Social Episodes', in R. Harre \& L. van Langenhove (eds.) Positioning Theory. pp. 1-13, Oxford: Blackwell. 
Mills, C.W. (1940) 'Situated Actions and Vocabularies of Motive', American Sociological Review 5(6): 904-913.

Peters, T. \& Waterman, R. (1982) In Search of Excellence. New York: Harper and Row.

Potter, J. (1996) Representing Reality: Discourse, Rhetoric and Social Construction. London: Sage.

Scott, M. \& Lyman, S. (1968) ‘Accounts’, American Sociological Review, 33(1): 46-62.

Skoldberg, K. (2002) The Poetic Logic of Administration: Styles and Changes of Style in the art of Organizing. London: Routledge.

Sims, D. (2003) 'Between the Millstones: A Narrative Account of the Vulnerability of Middle Managers' Storying’, Human Relations 56(10): 1195-1211.

Stokoe, E. \& Edwards, D. (2006) 'Story formulations in talk-in-interaction', Narrative Inquiry 16(1): 56-65.

Turner, V. (1982) From Ritual to Theatre: The Human Seriousness of Play. New York: Performing Arts Journal Publications.

van Langenhove, L. \& Harre, R. (1999) 'Introducing Positioning Theory', in R. Harre \& L. van Langenhove (eds.) Positioning Theory. pp. 14-31, Oxford: Blackwell.

Zilber, T.B. (2007) 'Stories and the Discursive Dynamics of Institutional Entrepreneurship: The Case of Israeli High-tech after the Bubble', Organization Studies, 28(7): 10351054. 